\title{
The role of macrophage scavenger receptor 1 (Msr1) in prion pathogenesis
}

\author{
Bei $\mathrm{Li}^{1} \cdot$ Meiling Chen ${ }^{1} \cdot$ Adriano Aguzzi $^{2}$ (1) $\cdot$ Caihong Zhu ${ }^{1}$
}

Received: 11 November 2020 / Revised: 1 February 2021 / Accepted: 7 March 2021 / Published online: 23 March 2021

(C) The Author(s) 2021

\begin{abstract}
The progression of prion diseases is accompanied by the accumulation of prions in the brain. Ablation of microglia enhances prion accumulation and accelerates disease progression, suggesting that microglia play a neuroprotective role by clearing prions. However, the mechanisms underlying the phagocytosis and clearance of prion are largely unknown. The macrophage scavenger receptor 1 (Msr1) is an important phagocytic receptor expressed by microglia in the brain and is involved in the uptake and clearance of soluble amyloid- $\beta$. We therefore asked whether Msrl might play a role in prion clearance and assessed the scavenger function of Msr1 in prion pathogenesis. We found that Msr1 expression was upregulated in prion-infected mouse brains. However, Msr1 deficiency did not change prion disease progression or lesion patterns. Prion deposition in Msr1 deficient mice was similar to their wild-type littermates. In addition, prion-induced neuroinflammation was not affected by Msr1 ablation. We conclude that Msr1 does not play a major role in prion pathogenesis.
\end{abstract}

\section{Key messages}

- Msr1 expression is upregulated in prion-infected mouse brains at the terminal stage

- Msr1 deficiency does not affect prion disease progression

- Msr1 does not play a major role in prion clearance or prion pathogenesis

- Microglia-mediated phagocytosis and clearance of $A \beta$ and prion may adopt distinct molecular pathways

Keywords Prion disease $\cdot$ Microglia $\cdot$ Macrophage scavenger receptor $1 \cdot$ Phagocytosis $\cdot$ Neuroinflammation

\section{Introduction}

Prion diseases are transmissible and fatal neurodegenerative disorders that affect both human and animals. This disease category comprises Creutzfeldt-Jakob disease (CJD), fatal familial insomnia (FFI) and Gerstmann-Sträussler-Scheinker syndrome (GSS) in humans, scrapie in sheep and goat, bovine spongiform encephalopathy (BSE) in cattle, and chronic wasting disease (CWD) in cervids [1]. Prion diseases are thus

Adriano Aguzzi

Adriano.Aguzzi@usz.ch

Caihong Zhu

Caihong_Zhu@fudan.edu.cn

1 School of Basic Medical Sciences, Fudan University, Dong'An Road 130, Shanghai 200032, China

2 Institute of Neuropathology, University Hospital Zurich, Schmelzbergstrasse 12, CH-8091 Zurich, Switzerland far incurable. The infectious agent mainly consists of scrapie prion protein $\left(\mathrm{PrP}^{\mathrm{Sc}}\right)$, which is a misfolded isoform of the host-encoded cellular prion protein $\left(\operatorname{PrP}^{\mathrm{C}}\right) . \operatorname{PrP}^{\mathrm{Sc}}$ acts as a propagon, which can seed a self-perpetuating reaction to recruit and convert $\operatorname{PrP}^{\mathrm{C}}$ to an aggregated conformation. The deposition of $\mathrm{PrP}^{\mathrm{Sc}}$ in the central nervous system (CNS), together with neuronal loss, spongiform changes (or termed vacuolization), astrogliosis and conspicuous microglial activation, constitutes the characteristic molecular pathology of prion disease [2].

Microglia are the primary innate immune cells and phagocytes of the CNS, exerting a neuroprotective role in prion pathogenesis [3]. We have reported that pharmacogenetic removal of microglia greatly enhances $\operatorname{PrP}^{\mathrm{Sc}}$ accumulation in prion-infected cultured organotypic cerebellar slices (COCS) and in mice $[4,5]$. However, the molecular mechanisms underlying prion clearance by microglia are largely unknown [1]. Lack of milk-fat globule EGF factor VIII (Mfge8) was reported to enhance prion pathogenesis in a mouse strain- 
dependent manner, suggesting that Mfge8 can facilitate engulfment of $\operatorname{PrP}^{\mathrm{Sc}}$ aggregates by microglia $[6,7]$. Developmental endothelial locuse1 (Del-1) is a structural and functional homolog of Mfge8 and therefore was a further candidate modifier of prion removal. However, Del-1 deficiency neither changed prion deposition nor prion pathogenesis in mice, suggesting that Del-1 does not complement Mfge8 in prion clearance [8]. Also triggering receptor expressed on myeloid cells 2 (TREM2), a phagocytic receptor expressed on microglia, modulates prion-induced microglial activation but does not contribute to prion clearance [9]. Hence, the molecules that are involved in prion clearance are complex and require further study.

Microglia express various receptors that facilitate sensing and phagocytosis of pathogens and misfolded protein aggregates; these include toll-like receptors (TLRs), scavenger receptors(SRs), Fc receptors, complement receptors, triggering receptor expressed on myeloid cells-2 (TREM2), myeloid cell surface antigen CD33, and others [10]. Importantly, variants of the TREM2 and CD33 genes are risk factors for Alzheimer's disease (AD) [11-13], probably due to impaired uptake and clearance of amyloid- $\beta(A \beta)[14,15]$. Although TREM2 is not a main transducer of prion clearance [9], the role of other microglial receptors in prion pathogenesis merits further investigations.

Msr1, also known as scavenger receptor a1 (Scara1), is a type II transmembrane glycoprotein mainly expressed by microglia in CNS [16]. Msr1 has been involved in many macrophage-associated physiological and pathological conditions such as neurodegenerative diseases [17]. As an important phagocytic receptor, Msr1 can mediate uptake of fibrillary amyloid $\beta(A \beta)$ in vitro [18-20]. Msr1 deficiency in a mouse model of AD markedly accelerates $A \beta$ accumulation and disease progression, whereas pharmacological upregulation of Msr1 leads to enhanced A $\beta$ clearance. These results collectively suggest that Msr1 is essential for clearing soluble $A \beta$ $[21,22]$. Since both $A \beta$ and prion are extracellular misfolded protein aggregates, they may share similar molecular pathways by which microglia take up and degrade the protein aggregates.

In this study, we aimed to investigate whether Msr1 may have a similar function in prion clearance and pathogenesis. We first determined the Msr1 expression in a mouse model of prion disease and found Msr1 expression was significantly increased in prion-infected mouse brain. After prion inoculation, we then observed that $\mathrm{Msr}^{-/-}$mice showed disease progression similar to their hemizygous $\left(\mathrm{Msrl}^{+/}\right)$and wild-type $\left(\mathrm{Msrl}^{+/+}\right)$littermates. Besides, prion deposition and seeding dose were not altered by Msr1 deficiency, suggesting that Msr1 is not involved in prion clearance. Furthermore, Msr1 deficiency did not affect prion-induced neuroinflammation. We therefor conclude that Msr1 is not a major player in prion clearance and does not influence prion pathogenesis.

\section{Material and methods}

\section{Ethical statement}

All animal experiments were carried out in strict accordance with the Rules and Regulations for the Protection of Animal Rights (Tierschutzgesetz and Tierschutzverordnung) of the Swiss Bundesamt für Lebensmittelsicherheit und Veterinärwesen and were pre-emptively approved by the Animal Welfare Committee of the Canton of Zürich (permit \# 41/2012).

\section{Animals}

$\mathrm{Msr}^{-\mathrm{T}_{-}}$mice were generated by inserting a neomycin cassette into the EcoRI site in exon 4, which encodes the alpha helical coiled-coil structure essential for the formation of functional trimeric receptors ([23]; JAX stock \#006096). $\mathrm{Msr}^{-/-}$mice were first backcrossed to C57BL/6 J mice to obtain $\mathrm{MsrI}^{+/-}$ offspring, which were then intercrossed to generate $\mathrm{Msr}^{+/+}$ (wild type), $\mathrm{Msrl}^{+/-}$and $\mathrm{Msrl}^{-/-}$mice for experiments described here. All animals were maintained in high hygienic grade facility under a $12 \mathrm{~h}$ light/12 $\mathrm{h}$ dark cycle (from $7 \mathrm{am}$ to $7 \mathrm{pm})$ at $21 \pm 1{ }^{\circ} \mathrm{C}$ and fed with diet and water ad libitum.

\section{Prion inoculation}

Mice were intracerebrally (i.c) inoculated with $30 \mu \mathrm{l}$ of brain homogenate diluted in PBS with 5\% BSA and containing $3 \times$ $10^{5}$ LD50 units of the Rocky Mountain Laboratories scrapie strain (passage 6, thus called RML6). Mice were monitored and actions were taken to minimize animal suffering and distress according to details described previously [24]. Scrapie was diagnosed according to clinical criteria (ataxia, limb weakness, front leg paresis and rolling). Mice were sacrificed by $\mathrm{CO}_{2}$ inhalation on the day of appearance of terminal clinical signs of scrapie (specific criteria referred to [24]), organs were taken and then were either snap-frozen for biochemical analysis or fixed in $4 \%$ formalin for histological assessment. The time elapsed from prion inoculation to the terminal stage of disease was defined as incubation time for the survival study.

\section{Quantitative real-time PCR (qRT-PCR)}

Total RNA from was extracted using TRIzol (Invitrogen Life Technologies) according to the manufacturer's instruction. The quality of RNA was analyzed by Bioanalyzer 2100 (Agilent Technologies), RNAs with RIN $>8$ were used for cDNA synthesis. cDNAs were synthesized from $\sim 1 \mu \mathrm{g}$ total RNA using QuantiTect Reverse Transcription kit (QIAGEN) according to the manufacturer's instruction. Quantitative realtime PCR (qRT-PCR) was performed using the SYBR Green 
PCR Master Mix (Roche) on a ViiA7 Real-Time PCR system (Applied Biosystems). The following primer pairs were used: GAPDH sense 5'-CCA CCC CAG CAA GGA GAC T-3'; antisense, 5'-GAA ATT GTG AGG GAG ATG CT-3'. Msr1 sense 5'- TGA ACG AGA GGA TGC TGA CTG -3'; antisense, 5'- GGA GGG GCC ATT TTT AGT GC -3'. TNF $\alpha$ sense, 5'-CAT CTT CTC AAA ATT CGA GTG ACA A-3'; antisense, 5'-TGG GAG TAG ACA AGG TAC AAC CC-3'. IL-1 $\beta$ sense, $5^{\prime}$-CAA CCA ACA AGT GAT ATT CTC CAT G-3'; antisense, 5'-GAT CCA CAC TCT CCA GCT GCA-3'. IL-6 sense, 5'-TCC AAT GCT CTC CTA ACA GAT AAG3'; antisense, 5'-CAA GAT GAA TTG GAT GGT CTT G $3^{\prime}$. Expression levels were normalized using GAPDH.

\section{Immunohistochemistry}

Prion-infected brain tissues were harvested and fixed in formalin, followed by treatment with concentrated formic acid for $60 \mathrm{~min}$ to inactivate prion infectivity and embedded in paraffin. Paraffin sections $(2 \mu \mathrm{m})$ of brains were stained with hematoxylin/eosin (HE) to visualize prion-induced lesions and vacuolation. For the histological detection of partially proteinase K-resistant prion protein deposition, deparaffinized sections were pretreated with formaldehyde for $30 \mathrm{~min}$ and $98 \%$ formic acid for $6 \mathrm{~min}$, and then washed in distilled water for $30 \mathrm{~min}$. Sections were incubated in Ventana buffer and stains were performed on a NEXEX immunohistochemistry robot (Ventana instruments, Switzerland) using an IVIEW DAB Detection Kit (Ventana). After incubation with protease 1 (Ventana) for $16 \mathrm{~min}$, sections were incubated with anti-PrP SAF-84 (1:200, SPI bio, A03208) for $32 \mathrm{~min}$. Sections were counterstained with hematoxylin. To detect astrogliosis and microglial activation, brain sections were deparaffinized through graded alcohols, anti-GFAP antibody (1:300; DAKO, Carpinteria, CA) were applied for astrogliosis, and anti-AIF1 antibody (1:1000; Wako Chemicals GmbH, Germany) was used for highlighting activated microglial cells. Stainings were visualized using DAB (Sigma-Aldrich), and hematoxylin counterstain was subsequently applied. Sections were imaged using a Zeiss Axiophot light microscope. Quantification of SAF84 staining was performed on acquired images. Regions of interest were drawn, and the average signal density was quantified using Image $\mathrm{J}$ software (National Institutes of Health).

\section{Western blot analysis}

To detect $\operatorname{PrP}^{\mathrm{C}}$ in the mouse brains, one hemisphere of each brain was homogenized with RIPA buffer. Total protein concentration was determined using the bicinchoninic acid assay (Pierce). $\sim 8 \mu \mathrm{g}$ proteins were loaded and separated on a $12 \%$ Bis-Tris polyacrylamide gel (NuPAGE, Invitrogen) and then blotted onto a nitrocellulose membrane. Membranes were blocked with 5\% wt/vol Topblock (LuBioScience) in PBS supplemented with $0.1 \%$ Tween 20 (vol/vol) and incubated with primary antibodies POM1 in $1 \%$ Topblock $\left(400 \mathrm{ng} \mathrm{ml}^{-1}\right.$ ) overnight. After washing, the membranes were then incubated with secondary antibody horseradish peroxidase (HRP)-conjugated goat anti-mouse IgG (1:10,000, Jackson ImmunoResearch, 115-035-003). Blots were developed using Luminata Crescendo Western HRP substrate (Millipore) and visualized using the Stella system (model 3000, Bio-Rad). To avoid variation in loading, the same blots were stripped and incubated with anti-actin antibody (1:10,000, Millipore). The $\operatorname{PrP}^{\mathrm{C}}$ signals were normalized to actin as a loading control.

To detect $\mathrm{PrP}^{\mathrm{Sc}}$, prion infected forebrains were homogenized in sterile $0.32 \mathrm{M}$ sucrose in PBS. Total protein concentration was determined using the bicinchoninic acid assay (Pierce). Samples were adjusted to $20 \mu \mathrm{g}$ protein in $20 \mu \mathrm{l}$ and digested with $25 \mu \mathrm{g} \mathrm{ml}{ }^{-1}$ proteinase $\mathrm{K}$ for $30 \mathrm{~min}$ at 37 ${ }^{\circ} \mathrm{C}$. PK digestion was stopped by adding loading buffer (Invitrogen) and boiling samples at $95{ }^{\circ} \mathrm{C}$ for $5 \mathrm{~min}$. Proteins were then separated on a $12 \%$ Bis-Tris polyacrylamide gel (NuPAGE, Invitrogen) and blotted onto a nitrocellulose membrane. POM1 and horseradish peroxidase (HRP)-conjugated goat anti-mouse IgG were used as primary and secondary antibodies, respectively. Blots were developed using Luminata Crescendo Western HRP substrate (Millipore) and visualized using the FUJIFILM LAS-3000 system. To detect GFAP and AIF1 in prion-infected brains by Western blot, $20 \mu \mathrm{g}$ of total brain protein were loaded and anti-GFAP antibody (D1F4Q) XP Rabbit mAb (1:3000; Cell Signaling Technology, 12389), anti-AIF1 antibody (1:1000; Wako Chemicals GmbH, Germany, 019-19741) and horseradish peroxidase (HRP)-conjugated goat anti-rabbit IgG (1:10,000, Jackson ImmunoResearch, 111-035-045) were used as primary and secondary antibodies, respectively. Actin was used as the loading control.

\section{Real-time quaking induced conversion assay (RT- QuIC)}

RT-QuIC assays of prion-infected mouse brain homogenates were performed as previously described [8, 25]. Briefly, recombinant hamster full-length (23-231) PrP was expressed in Rosetta2(DE3)pLysS E. coli competent cells and purified by affinity chromatography using $\mathrm{Ni}^{+}{ }^{+}$-nitrilotriacetic acid Superflow resin (QIAGEN). In the RT-QuIC assay, recombinant $\mathrm{HaPrP}$ was used as substrate for $\mathrm{PrP}^{\mathrm{Sc}}$-catalyzed conversion. RT-QuIC reactions containing HaPrP substrate protein at a final concentration of $0.1 \mathrm{mg} \mathrm{mL}^{-1}$ in $\mathrm{PBS}(\mathrm{pH} 7.4$ ), $170 \mathrm{mM} \mathrm{NaCl}, 10 \mu \mathrm{M}$ EDTA, and $10 \mu \mathrm{M}$ Thioflavin T were seeded with $2 \mu \mathrm{L}$ of serially diluted brain homogenates in a total reaction volume of $100 \mu \mathrm{L}$. NBH- and RML6-treated brain homogenates were used as negative and positive controls, respectively. The RT-QuIC reactions were amplified at 
$42{ }^{\circ} \mathrm{C}$ for $100 \mathrm{~h}$ with intermittent shaking cycles of $90 \mathrm{~s}$ shaking at $900 \mathrm{rpm}$ in double orbital mode and $30 \mathrm{~s}$ resting using a FLUOstar Omega microplate reader (BMG Labtech). Aggregate formation was followed by measuring the thioflavin $\mathrm{T}$ fluorescence every $15 \mathrm{~min}(450 \mathrm{~nm}$ excitation, $480 \mathrm{~nm}$ emission; bottom read mode).

\section{Statistical analysis}

Results are presented as the mean of replicas \pm standard error of the mean (SEM). Statistical significance between experimental groups was assessed using an unpaired Student's $t$ test. For prion inoculation experiments, incubation times were analyzed using the Kaplan-Meier method and compared between groups using Log-rank (Mantel-Cox) test. $p$ values $<$ 0.05 were considered statistically significant.

\section{Results}

\section{Prion infection upregulates Msr1 expression in the mouse brain}

Expression of Msr 1 could be upregulated by various forms of brain injury and neurodegeneration [16, 26-29]. To test whether prion infection affects $M s r l$ expression in the mouse brain, we intracerebrally (i.c) inoculated $30 \mu \mathrm{l}$ of diluted CD1 mouse brain homogenate containing $3 \times 10^{5}$ LD50 (50\% lethal dose) units of RML6 (a prion strain originated from the Rocky Mountain Laboratory, serially passaged to No. 6, hence termed RML6) into C57BL/6 J mice. C57BL/6 J littermates inoculated with noninfectious brain homogenate (NBH) were used as control. Prion-inoculated mice were euthanized and brains were collected when they showed severe scrapie sign and reached the terminal stage of disease, NBHinoculated control mice were sacrificed after the same incubation time. Since we could not commercially obtain a sensitive and specific antibody detecting the Msrl protein in mouse brains (supplemental Fig. 1), we assessed Msrl expression levels using quantitative reverse-transcription PCR (qRTPCR). The results showed that $M s r 1$ expression was significantly enhanced in prion-inoculated mouse brain, compared to NBH inoculated mouse (Fig. 1a), suggesting that Msrl expression can be efficiently upregulated by prion infection.

Consistent with our qRT-PCR results, a time course study of hippocampal transcriptome of prion-infected mice by RNA sequencing (RNA-Seq) showed that Msr1 mRNA level was significantly increased at the terminal stage of RMLinoculated mice, but not in NBH-inoculated control mice (supplemental Fig. 2a). Interestingly, however, during the preclinical stage and even at the early stage after onset of clinical symptoms, Msr 1 mRNA levels were not significantly changed (supplemental Fig. 2a). Considering that Msr1 is mainly expressed by microglia in the CNS, and the microglia can be conspicuously activated and proliferate upon prion infection, we aimed to determine whether the upregulation of Msrl mRNA is due to the increased microglia number. We found that mRNA levels of various microglia markers including Aif1, CD68, and Itgax were almost simultaneously induced in prion-inoculated mice from 16 weeks postinoculation on (supplemental Figs. 2b-d), when Msrl mRNA was not significantly altered yet [30]. Moreover, a cell-type-specific ribosomal profiling using CX3CR1-Cre ${ }^{\text {ER }}$ mice revealed that Msr1 was indeed upregulated in microglia only at the terminal stage (supplemental Figure 2E) [31]. Therefore, these results suggest that upregulation of Msrl expression was not merely an effect of increased microglia number after prion infection, but displayed unique pattern and dynamics.

$\mathrm{PrP}^{\mathrm{C}}$ expression levels in mouse brains are the major determinants of the susceptibility to prion diseases and progression rate of the diseases [32, 33]. To assess whether Msr1 deficiency could influence $\operatorname{PrP}^{\mathrm{C}}$ expression, we performed qRT-PCR and Western blot to measure Prnp mRNA transcripts and $\mathrm{PrP}^{\mathrm{C}}$ protein levels in $\mathrm{Msrl}^{+/+}, \mathrm{Msrl}^{+/-}$, and $\mathrm{Msr}^{-/ /}$littermates. The results showed that Msrl deficiency altered neither the Prnp mRNA (Fig. 1b) nor the protein levels of $\operatorname{PrP}^{\mathrm{C}}$ (Figs. 1c-d, uncropped Western blots are shown in Supplementary Fig. 3a-b) in mouse brains.

\section{Prion disease progression, lesion pattern, or PrP ${ }^{S c}$ accumulation are not altered by Msr1 deficiency}

To assess the function of Msr1 in prion pathogenesis, we next tested whether Msr1 ablation could affect prion disease progression and alter prion-mediated lesion pattern in mouse brains. We intracerebrally (i.c) inoculated $30 \mu \mathrm{l}$ of RML6 prions into $\mathrm{Msrl}^{+/+}, \mathrm{Msrl}^{+/-}$, and $\mathrm{Msrl}^{-/-}$littermates. RML6inoculated mice were checked and monitored every other day for scrapie symptoms. Mice were euthanized and brains were collected when they showed severe scrapie sign and reached the terminal stage of disease. Incubation times were calculated as the time from initial prion inoculation until terminal disease stage. We observed that all $\mathrm{Msr}^{+/+}, \mathrm{Msrl}^{+/-}$, and $\mathrm{Msrl}^{-/-}$mice succumbed to prion disease at a similar progression rate (median survival: $179 \mathrm{dpi}$ for $M s r 1^{+/+}$mice $(n=17), 186 \mathrm{dpi}$ for $\operatorname{Msr}^{+/-}(n=25)$ and $183.5 \mathrm{dpi}$ for $\mathrm{Msr}^{-/-}$mice $(n=14), p=$ 0.99) (Fig. 2a). The above results indicate that Msr1 ablation does not overtly influence progression of prion disease.

We then analyzed and compared the histology of brain sections collected and prepared from RML6-inoculated terminally sick $\mathrm{Msrl}^{+/+}, \mathrm{Msrl}^{+/-}$and $\mathrm{Msrl}^{-/-}$mice. The classical histological characteristics of prion disease, especially the spongiform changes (or vacuolation), were observed in all mice in different groups. Lesion pattern analysis also failed to show any qualitative distinctions between different 
a

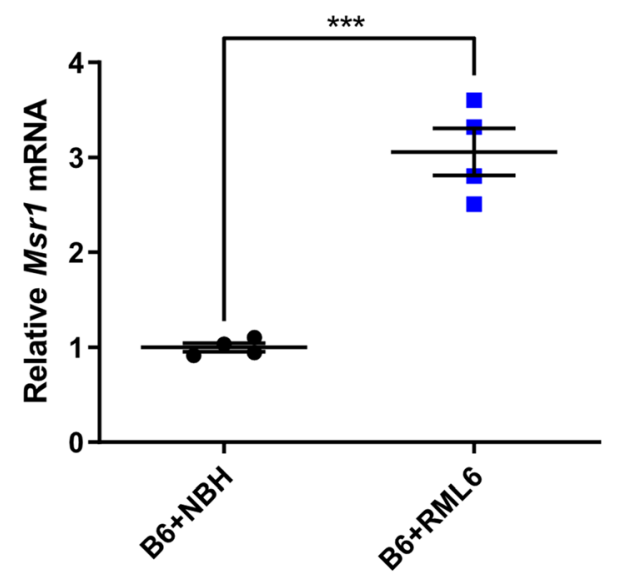

C

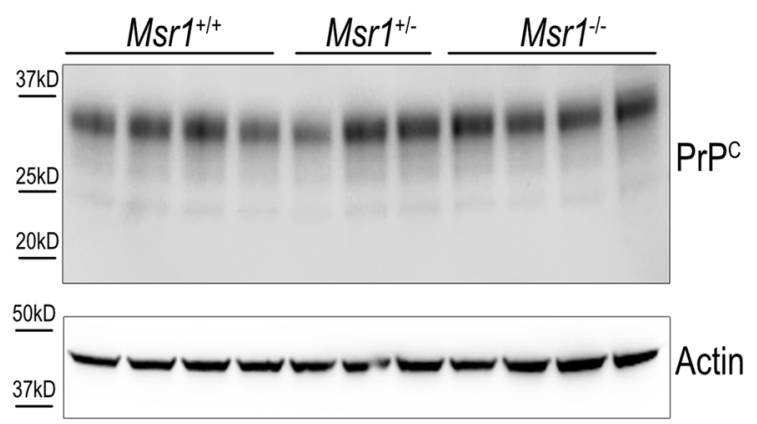

b

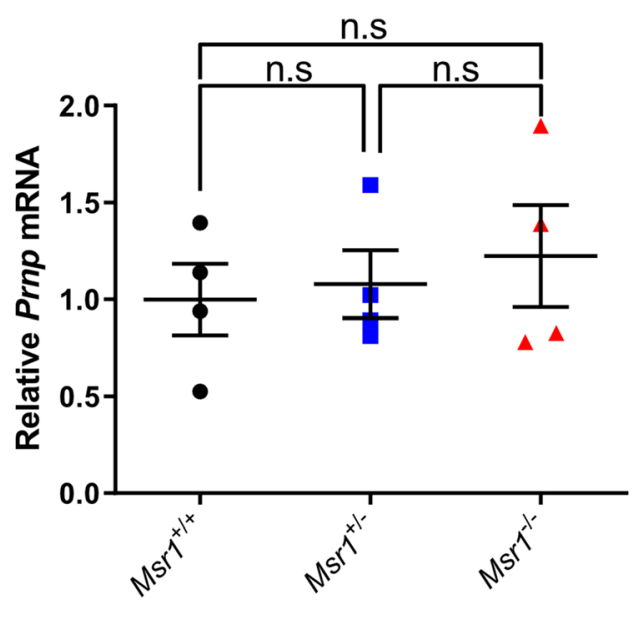

d

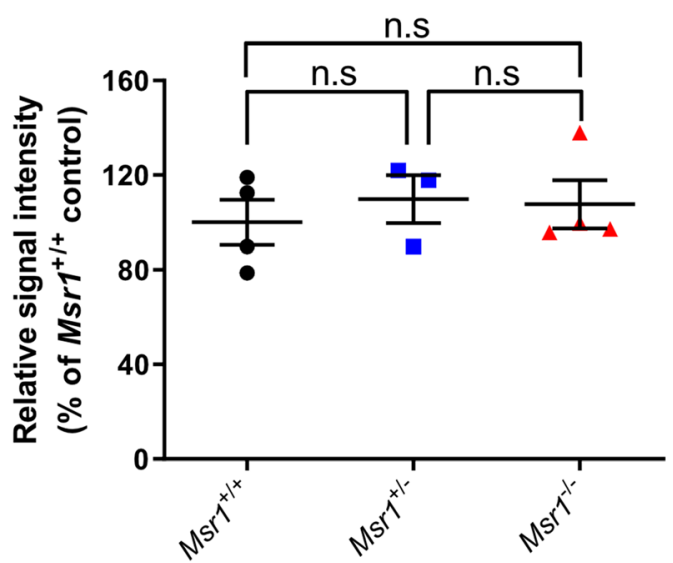

mouse brains $(n=3 \sim 4, n . s p>0.05)$. No significant difference of $\operatorname{Pr} P^{C}$ protein was observed between three groups. Abbreviations: Msrl, macrophage scavenger receptor 1 gene; Prnp, murine prion gene; $\operatorname{PrP}^{\mathrm{C}}$, cellular prion protein; qRT-PCR, quantitative real-time polymerase chain reaction; RML6, Rocky Mountain Laboratories scrapie strain, passage 6; NBH, noninfectious brain homogenates; WT, wild type

$\mathrm{Msr}^{+/-}$, and $\mathrm{Msrl}^{-/-}$mice by real time-quaking induced conversion assay (RT-QuIC). We detected an undistinguishable $50 \%$ seeding dose (SD50) of prion in all three groups (Fig. 2e). Taken together, these results indicate that Msrl does not play a major role in prion clearance or $\operatorname{PrP}^{\mathrm{Sc}}$ accumulation in mouse brains.

\section{Prion-induced neuroinflammation is not affected by Msr1 deficiency}

Msr1 is a scavenger receptor that could modulate immune response in CNS [34-36]. To test whether Msr1 exhibits an anti-inflammatory function in prion pathogenesis, we analyzed and compared astrogliosis and microglial activation in prion-infected terminally sick $\mathrm{Msrl}^{+/+}, \mathrm{Msrl}^{\mathrm{H}^{+/}}$and $\mathrm{Msrl}^{-/-}$ mice. First, histology and Western blots did not identify obvious differences in GFAP (glial fibrillary acidic protein, an 
a

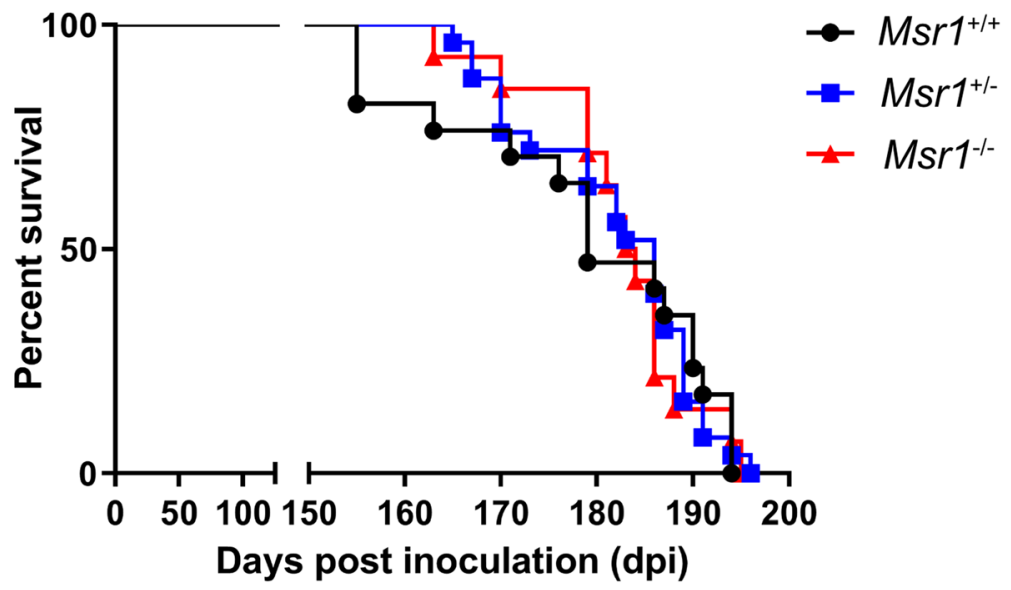

b
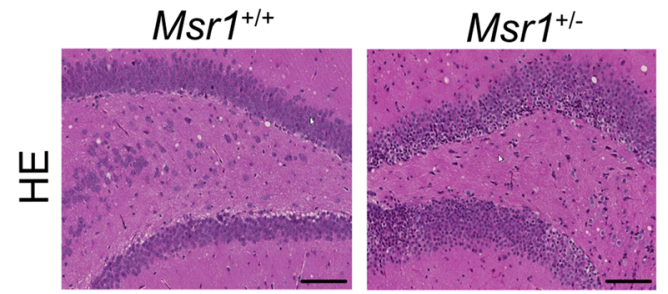

$\mathrm{Msr1}^{-1-}$
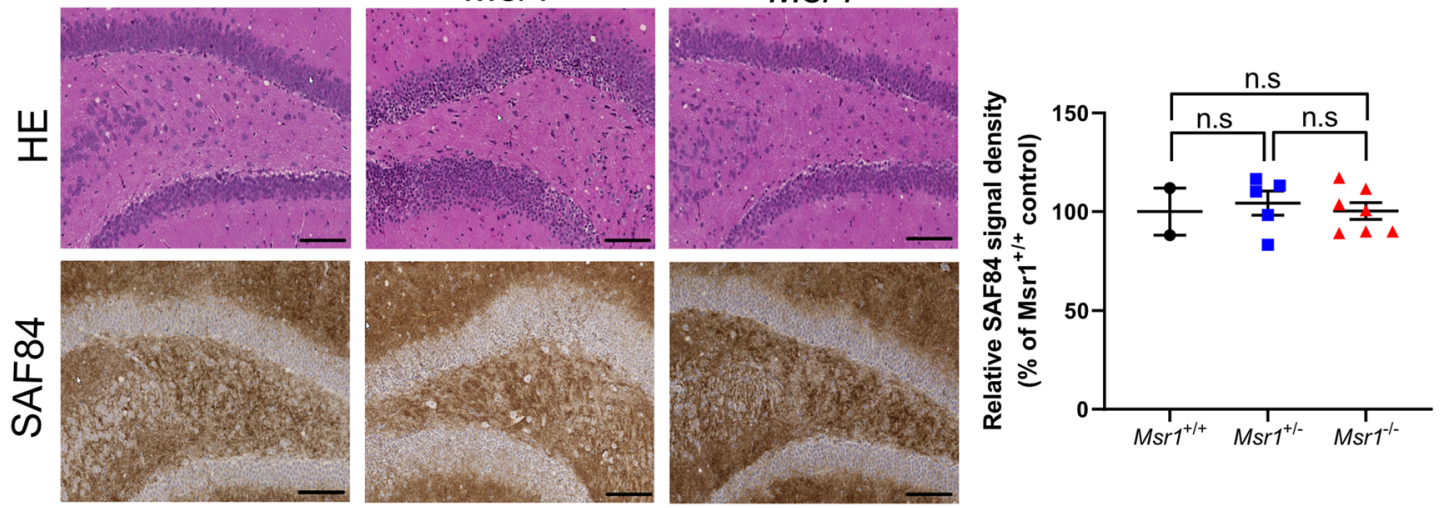

c

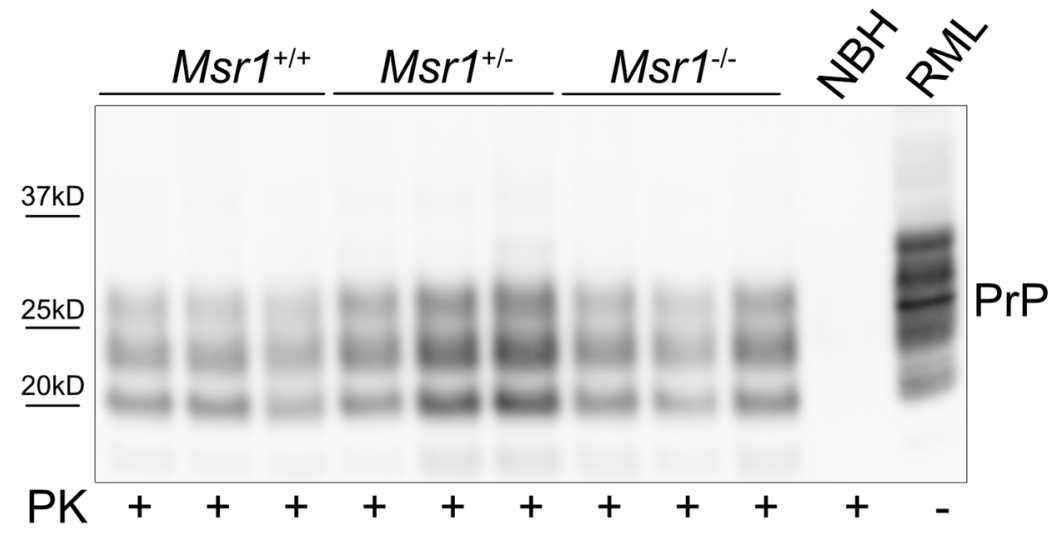

d

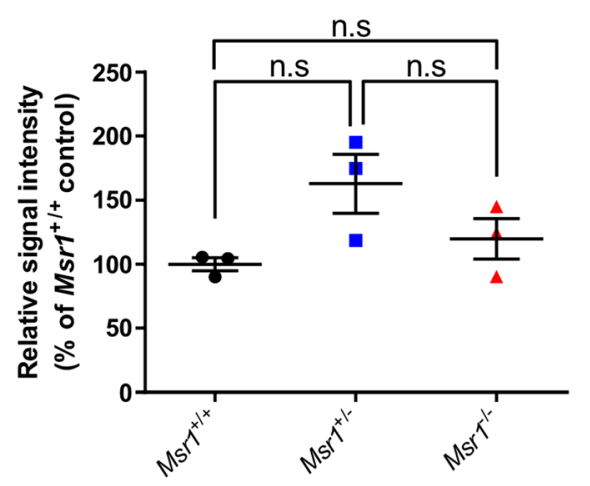

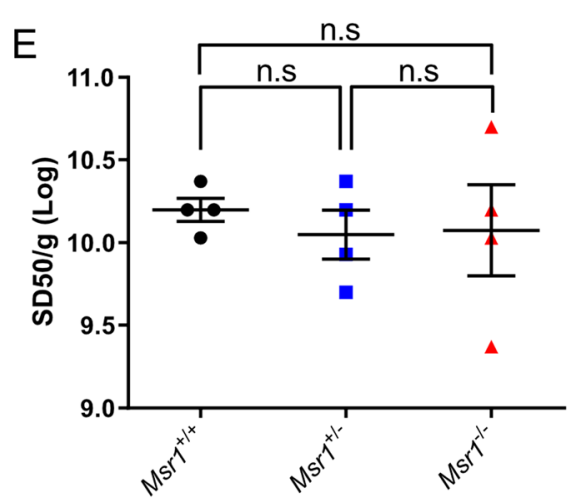


4 Fig. 2 (a) Survival curve of $\mathrm{Msrl}^{+/+}$(WT), $M s r \mathrm{I}^{+/-}$and $\mathrm{Msrl}^{-/-}$ littermates intracerebrally inoculated with RML6. There was no significant difference between three groups in both genders $(n=14-25$, n.s $p>0.05$ ). (b) Left: Representative histology of terminally sick mouse brains from $\mathrm{Msrl}^{+/+}$(WT), $\mathrm{Msrl}^{+/-}$and $\mathrm{Msrl}^{-/-}$littermates stained for H\&E and SAF84. Right: quantification of SAF84 staining. There was no obvious difference between three groups in vacuolation, lesion pattern and $\mathrm{PrP}^{\mathrm{Sc}}$ deposition in hippocampus $(n=2-7$, n.s $p>0.05)$. $\mathbf{c}$ and $\mathbf{d}$ Western blot for proteinase $\mathrm{K}$ resistant $\operatorname{PrP}^{\mathrm{Sc}}$ in terminally sick mouse brains (c) and densitometric quantification of the Western blot (d). There was no significantly difference between $\mathrm{Msr}^{+/+}$(WT), $\mathrm{Msrl}^{+/-}$and $M s r 1^{-/-}$littermates $(n=3$, n.s $p>0.05)$. (E) RT-QuIC assay of terminally sick mouse brains from $\mathrm{Msrl}^{+/+}$(WT), $\mathrm{Msrl}^{+/-}$and $\mathrm{Msr}^{\mathrm{T}^{-/}}$littermates showed similar level of $50 \%$ prion seeding dose in these three groups ( $n=4$, n.s $p>0.05$ ). Abbreviations: Msr1, macrophage scavenger receptor 1 ; $\operatorname{PrP}^{\mathrm{Sc}}$, scrapie-associated prion protein; RML6, Rocky Mountain Laboratories scrapie strain, passage 6; NBH, noninfectious brain homogenates; WT, wild type; RT-QuIC, real-time quaking-induced conversion assay

astrocytic marker) level between the three groups with different genotypes (Figs. 3a-b, uncropped Western blots are shown in Supplementary Figs. 3d-e). We next performed histological examinations and Western blots to detect AIF1 (allograft inflammatory factor-1, a microglial marker) in RML6-inoculated terminally sick $\mathrm{Msrl}^{+/+}, \mathrm{Msrl}^{+/}$, and $\mathrm{Msr}^{-/-}$mouse brains. We again observed similar levels of AIF1 between the three groups (Figs. 3c-d, uncropped Western blots are shown in Supplementary Figs. $3 \mathrm{f}-\mathrm{g}$ ). These results together suggest that Msr1 deficiency does not significantly affect prion-induced astrogliosis or microglial activation.

We next performed qRT-PCR to analyze the expression levels of proinflammatory cytokines (TNF $\alpha$, IL-1 $\beta$ and IL6) in RML6-inoculated terminally sick $\mathrm{Msrl}^{+/+}, \mathrm{Msrl}^{+/}$, and $M s r I^{-/-}$mouse brains. Again, this experiment failed to detect any overt differences in cytokine expression levels between the three groups (Fig. 3E), suggesting that Msrl ablation does not change the cytokine profiles of prion-infected mouse brains.

\section{Discussion}

It is becoming increasingly clear that neuroinflammation, characterized by astrogliosis and microglial activation, is a hallmark of many neurodegenerative diseases including prion diseases [37]. Emerging evidence from multiple genome-wide association studies (GWAS) suggests that microglia may play a central role in neurodegenerative diseases because most identified risk factors are expressed by microglia $[11,12$, 38-42]. The molecular mechanisms by which microglia contributes to the pathogenesis of neurodegenerative diseases are the subject of intense investigations. Insight into these questions will enable not only the understanding of disease pathogenesis but also the development of novel therapeutic strategies combating these disorders [43].
As the primary tissue-resident macrophages in the CNS, microglia exert diverse functions in the brain. Microglia play important roles during brain development by pruning neuronal synapses [44]. In adult brain, microglia could modulate learning and memory [45] and constantly survey their local milieu for signals of danger and injury, thus serving as important sensors and defenders upon challenges [46, 47]. Under pathological conditions such as in prion disease, microglia are found to play an overall neuroprotective role by clearing prions. Depletion or deficiency of microglia results in impaired prion clearance, enhanced $\mathrm{PrP}^{\mathrm{Sc}}$ deposition, and deteriorated prion pathogenesis [5]. These findings collectively highlight the need to better understand the molecular mechanisms underlying microglia-mediated prion clearance [3].

Msr1, a type II transmembrane glycoprotein expressed mainly by microglia in the brain [16], is a member of scavenger receptors that mediate endocytosis of a wide range of ligands including low-density lipoproteins, bacterial pathogens and dead cells $[48,49]$. The role of Msr1 in neurodegeneration such as Alzheimer's disease (AD) was first highlighted in an in vitro study showing that it could facilitate adhesion of microglia to fibrillar $A \beta$ [18]. This finding was further validated by a short hairpin RNA (shRNA) library screen [21]. In mouse models of AD, Msr1 deficiency impairs clearance of soluble $A \beta$ and results in increased $A \beta$ deposition and early mortality, whereas pharmacological upregulation of Msr1 leads to enhanced $A \beta$ clearance $[21,22]$. Therefore, it is reasonable to speculate that Msr1 could play a scavenger function for a broad range of misfolded protein aggregates including prions.

In this study, we tested whether Msr1 plays a scavenger function in prion pathogenesis, similar to that in mouse models of AD. Firstly, in contrast to what was observed in aged AD mouse models [50, 51], Msr1 expression was found to be upregulated at the terminal stage upon prion infection. After prion inoculation, we observed that $\mathrm{Msr}^{\mathrm{T}^{-/}}$mice experienced a similar incubation time compared with $\mathrm{Msrl}^{+/-}$and wild-type littermates, suggesting that Msr1 deficiency does not affect prion disease progression. Notably, the $\mathrm{PrP}^{\mathrm{Sc}}$ level and the prion seeding activity were not detectably affected by Msr1 deficiency, indicating that Msr1 is not a major contributor to prion clearance. Moreover, prion-induced neuroinflammation including astrocytosis and microglial activation was not altered in $\mathrm{Msr}^{-/-}$mouse brains, suggesting that Msr1 deficiency does not overtly affect prion-induced neuroinflammation. Together, these results indicate that Msr1 functions differently in $\mathrm{AD}$ and prion diseases.

\section{Limitations of the current study}

In the present study, we found that Msr 1 expression was upregulated in terminally sick prion-infected mouse brains detected by both qRT-PCR and RNA-seq. Longitudinal 
a

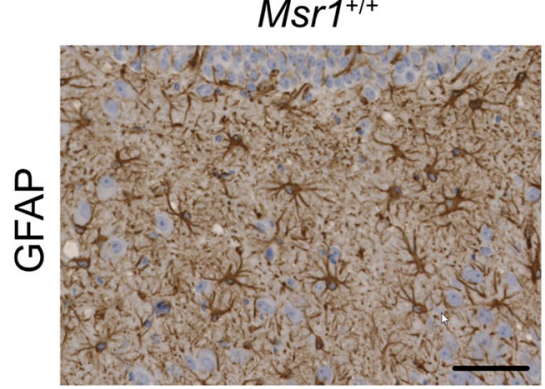

$\mathrm{Msr}^{+/-}$

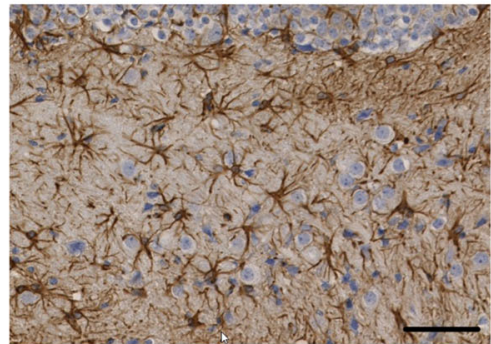

$\mathrm{Msr}^{-1-}$

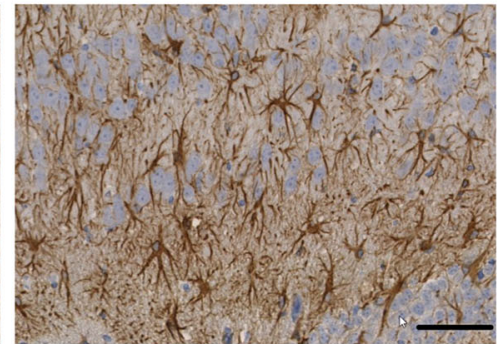

n.s
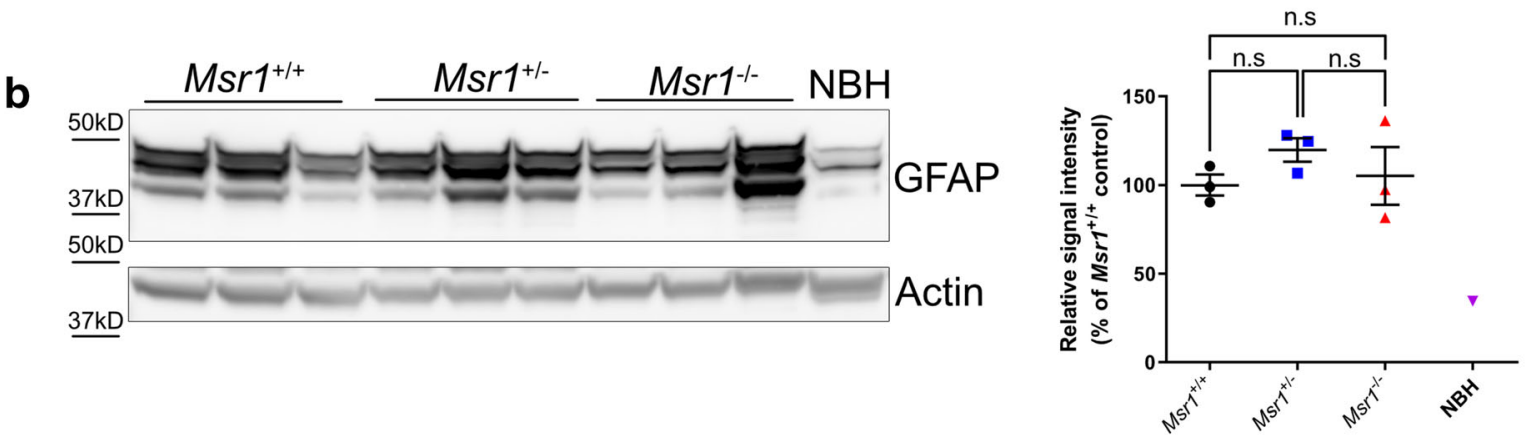

C

$\mathrm{Msr1}^{+/+}$

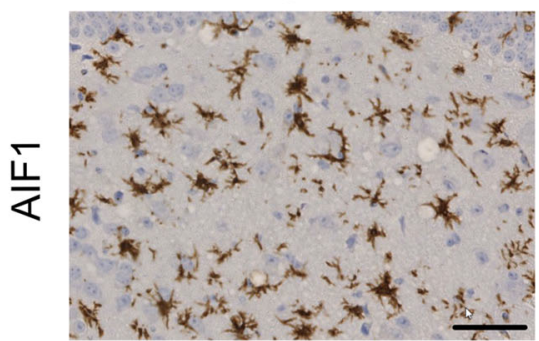

$\mathrm{Msr1}^{+/-}$

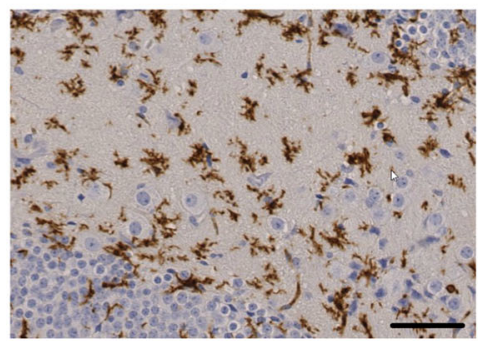

$\mathrm{Msr1}^{-1-}$

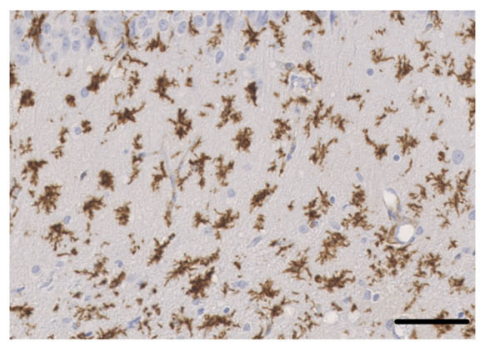

d

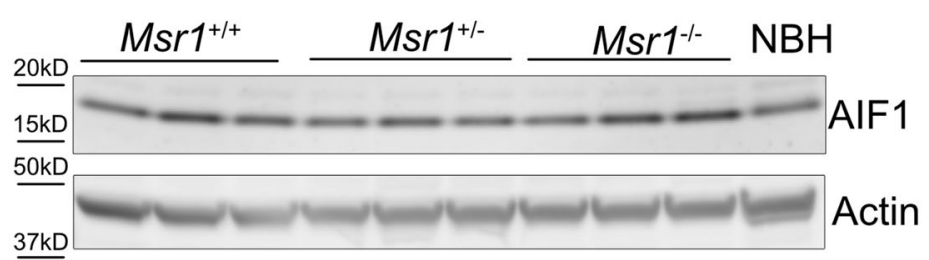

e
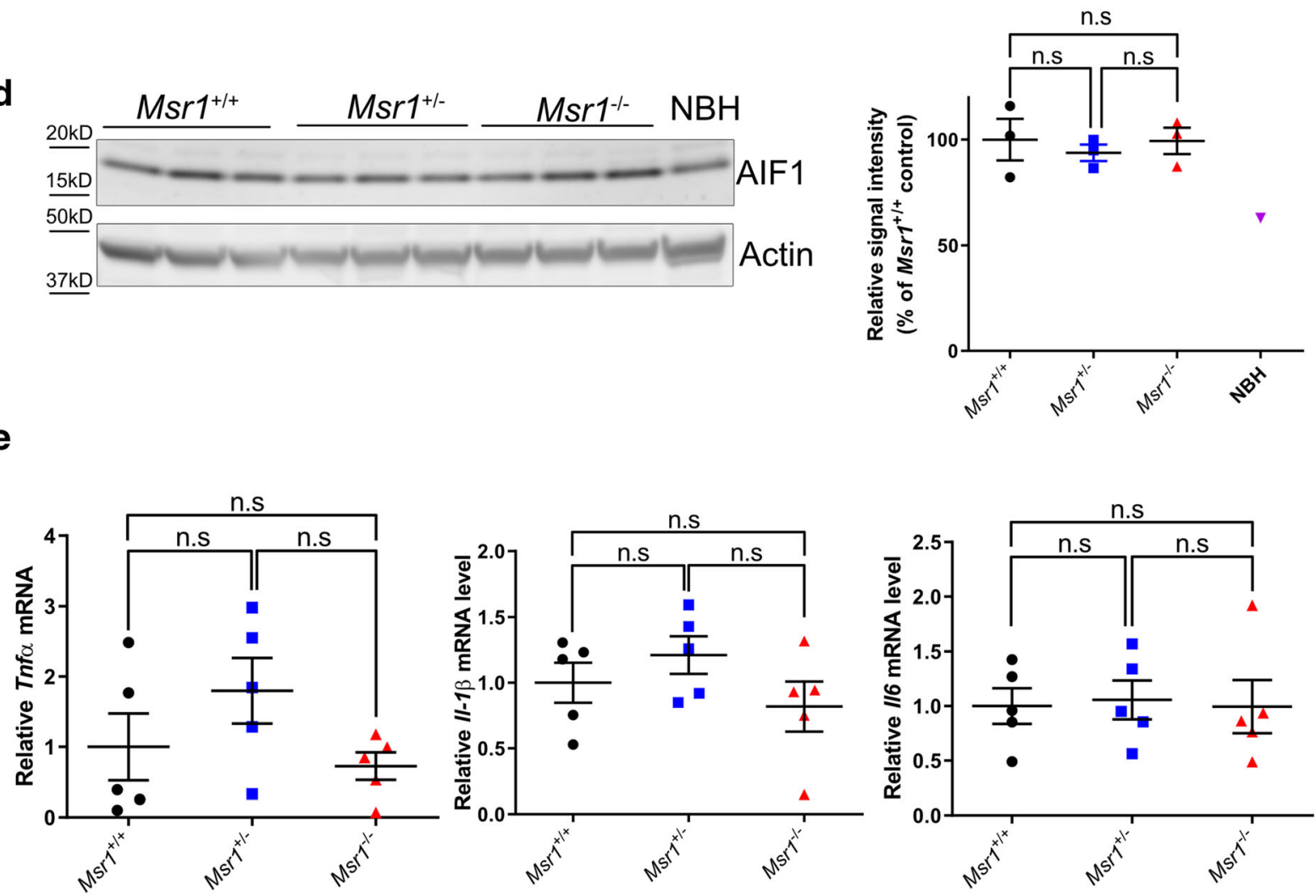
Fig. 3 a Representative immunohistochemical staining for GFAP in the hippocampus of terminally sick mouse brains from $\mathrm{Msrl}^{+/+}$(WT), $\mathrm{Msrl}^{+/-}$, and $\mathrm{Msrl}^{-/-}$littermates. b Left: Western blot for GFAP in terminally sick mouse brains. Right: densitometric quantification of the Western blot showed no significant difference of GFAP levels between $\mathrm{Msr}^{+/+}(\mathrm{WT}), \mathrm{Msrl}^{+/-}$and $M s r 1^{-/-}$littermates $(n=3-4$, n.s $p>0.05)$. c Representative immunohistochemical staining for AIF1 in the hippocampus of terminally sick mouse brains from $\mathrm{Msrl}^{+/+}$(WT), $\mathrm{Msrl}^{+/-}$and $\mathrm{Msrl}^{-/-}$littermates. d Left: Western blot for AIF1 in terminally sick mouse brains. Right: densitometric quantification of the Western blot showed no significant difference of AIF1 levels between $\mathrm{Msrl}^{+/+}(\mathrm{WT}), \mathrm{Msrl}^{+/-}$, and $M s r 1^{-/-}$littermates $(n=3-4$, n.s $p>0.05)$. e qRT-PCR of cytokines TNF $\alpha$, IL-1 $\beta$ and IL- 6 expression revealed similar mRNA levels of these cytokines (Tnf $\alpha, I l 1 \beta, I l 6)$ in terminally sick $M s r l^{+/+}(\mathrm{WT}), M_{s r}{ }^{+/-}$, and $M s r 1^{-/-}$littermates $(n=5$, n.s $p>0.05$ ). Abbreviations: Msr1, macrophage scavenger receptor 1; GFAP, glial fibrillary acidic protein; AIF1, Ionized calcium binding adaptor molecule 1; WT, wild type; qRT-PCR, quantitative real-time polymerase chain reaction

study showed that upregulation of Msr1 was not merely due to increased microglia number. Although both analyses were based on brain tissue containing a mixture of various cell types, a cell-type specific ribosomal profiling again found that Msr1 was significantly upregulated in microglia only at the terminal stage. Orthogonal methodologies, such as cell sorting followed by RNA-seq, would be required to confirm the microglia-specific Msrl expression pattern along the prion progression. Nevertheless, the late upregulation of Msr1 may explain that Msr1 have little impact on the prion pathogenesis. The varied temporal pattern and magnitude of changes of Msr1 expression between prion disease and $\mathrm{AD}$ may explain its differential functions in these diseases.

We performed prion infection experiments with an appropriate number of animals ( $\mathrm{n}=14 \sim 25$ mice per group) and conclude, with a high degree of confidence, that Msr1 deficiency did not overtly affect progression of prion disease. We randomly divided the samples into subgroups for either biochemical analysis or histology encompassing a relatively small number of samples ( $n=3-5$ mice per group). Because of the increased stochasticity inherent to such subgroups, we observed some variations in these analyses. Notwithstanding these limitations, our results point towards the same direction and are congruent with our conclusion that Msr1 does not play a major role in prion pathogenesis.

\section{Conclusion}

Collectively, these results indicate that Msr1 does not play a major role in prion pathogenesis. Together with the discrepant observations of TREM2 in AD and prion disease[9, 14], this study suggests that microglia-mediated phagocytosis and clearance of $A \beta$ and prion may adopt distinct molecular pathways. Further studies are needed to investigate molecular mechanisms underlying microglial uptake and clearance of prions.

Supplementary Information The online version contains supplementary material available at https://doi.org/10.1007/s00109-021-02061-7.

Acknowledgments We thank the teams of the Institute of Neuropathology, University Hospital Zurich and Department of Neurobiology, School of Basic Medical Sciences of Fudan University for technical assistance. The authors thank Elisabeth J. Rushing for reading and editing the article. A. Aguzzi is the recipient of an Advanced Grant of the European Research Council (ERC, No. 670958) and is supported by grants from the European Union (PRIORITY, NEURINOX), the Swiss National Foundation (SNF, including a Sinergia grant), the Swiss Initiative in Systems Biology, SystemsX.ch (PrionX, SynucleiX), and a Distinguished Scientist Award of the Nomis Foundation. C. Zhu is sponsored by Research Startup Funds of Fudan University, Shanghai Pujiang Program (No. 20PJ1401100) and National Natural Science Foundation of China (No. 82071436). The funders had no role in study design, data collection and analysis, decision to publish, or preparation of the manuscript.

Author's contributions C. Zhu and A. Aguzzi conceived the project and designed the experiments; B. Li, M. Chen, and C. Zhu conducted the experiments and acquired data. All authors contributed to data analysis.

Funding Open Access funding provided by Universität Zürich. A. Aguzzi is the recipient of an Advanced Grant of the European Research Council (ERC, No. 670958) and is supported by grants from the European Union (PRIORITY, NEURINOX), the Swiss National Foundation (SNF, including a Sinergia grant), the Swiss Initiative in Systems Biology, SystemsX.ch (PrionX, SynucleiX), and a Distinguished Scientist Award of the Nomis Foundation. C. Zhu is sponsored by Research Startup Funds of Fudan University, Shanghai Pujiang Program (No. 20PJ1401100) and National Natural Science Foundation of China (No. 82071436). The funders had no role in study design, data collection and analysis, decision to publish, or preparation of the manuscript.

Availability of data and material The authors confirm that the data and material supporting the findings of this study are available within the article and its supplementary materials.

Code availability Not applicable.

\section{Declarations}

Ethics approval All animal experiments were carried out in strict accordance with the Rules and Regulations for the Protection of Animal Rights (Tierschutzgesetz and Tierschutzverordnung) of the Swiss Bundesamt für Lebensmittelsicherheit und Veterinärwesen and were preemptively approved by the Animal Welfare Committee of the Canton of Zürich (permit \# 41/2012).

Consent to participate Not applicable.

Consent to publication Not applicable.

Conflict of interest The authors declare that they have no conflict of interest. 
Open Access This article is licensed under a Creative Commons Attribution 4.0 International License, which permits use, sharing, adaptation, distribution and reproduction in any medium or format, as long as you give appropriate credit to the original author(s) and the source, provide a link to the Creative Commons licence, and indicate if changes were made. The images or other third party material in this article are included in the article's Creative Commons licence, unless indicated otherwise in a credit line to the material. If material is not included in the article's Creative Commons licence and your intended use is not permitted by statutory regulation or exceeds the permitted use, you will need to obtain permission directly from the copyright holder. To view a copy of this licence, visit http://creativecommons.org/licenses/by/4.0/.

\section{References}

1. Aguzzi A, Nuvolone M, Zhu C (2013) The immunobiology of prion diseases. Nat Rev Immunol 13:888-902

2. Aguzzi A, Zhu C (2012) Five questions on prion diseases. PLoS Pathog 8:e1002651

3. Aguzzi A, Zhu C (2017) Microglia in prion diseases. J Clin Invest 127:3230-3239

4. Falsig J, Julius C, Margalith I, Schwarz P, Heppner FL, Aguzzi A (2008) A versatile prion replication assay in organotypic brain slices. Nat Neurosci 11:109-117

5. Zhu C, Herrmann US, Falsig J, Abakumova I, Nuvolone M, Schwarz P, Frauenknecht K, Rushing EJ, Aguzzi A (2016) A neuroprotective role for microglia in prion diseases. J Exp Med 213: $1047-1059$

6. Kranich J, Krautler NJ, Heinen E, Polymenidou M, Bridel C, Schildknecht A, Huber C, Kosco-Vilbois MH, Zinkernagel R, Miele G, Aguzzi A (2008) Follicular dendritic cells control engulfment of apoptotic bodies by secreting Mfge8. J Exp Med 205: 1293-1302

7. Kranich J, Krautler NJ, Falsig J, Ballmer B, Li S, Hutter G, Schwarz P, Moos R, Julius C, Miele G, Aguzzi A (2010) Engulfment of cerebral apoptotic bodies controls the course of prion disease in a mouse strain-dependent manner. J Exp Med 207:2271-2281

8. Zhu C, Li Z, Li B, Pfammatter M, Hornemann S, Aguzzi A (2019) Unaltered prion disease in mice lacking developmental endothelial locus-1. Neurobiol Aging 76:208-213

9. Zhu C, Herrmann US, Li B, Abakumova I, Moos R, Schwarz P, Rushing EJ, Colonna M, Aguzzi A (2015) Triggering receptor expressed on myeloid cells-2 is involved in prion-induced microglial activation but does not contribute to prion pathogenesis in mouse brains. Neurobiol Aging 36:1994-2003

10. Doens D, Fernandez PL (2014) Microglia receptors and their implications in the response to amyloid beta for Alzheimer's disease pathogenesis. J Neuroinflammation 11:48

11. Guerreiro R, Wojtas A, Bras J, Carrasquillo M, Rogaeva E, Majounie E, Cruchaga C, Sassi C, Kauwe JS, Younkin S, Hazrati L, Collinge J, Pocock J, Lashley T, Williams J, Lambert JC, Amouyel P, Goate A, Rademakers R, Morgan K, Powell J, St George-Hyslop P, Singleton A, Hardy J, Alzheimer Genetic Analysis Group (2013) TREM2 variants in Alzheimer's disease. N Engl J Med 368:117-127

12. Jonsson T, Stefansson H, Steinberg S, Jonsdottir I, Jonsson PV, Snaedal J, Bjornsson S, Huttenlocher J, Levey AI, Lah JJ, Rujescu D, Hampel H, Giegling I, Andreassen OA, Engedal K, Ulstein I, Djurovic S, Ibrahim-Verbaas C, Hofman A, Ikram MA, van Duijn CM, Thorsteinsdottir U, Kong A, Stefansson K (2013) Variant of TREM2 associated with the risk of Alzheimer's disease. N Engl J Med 368:107-116

13. Bradshaw EM, Chibnik LB, Keenan BT, Ottoboni L, Raj T, Tang A, Rosenkrantz LL, Imboywa S, Lee M, Von Korff A et al (2013)
CD33 Alzheimer's disease locus: altered monocyte function and amyloid biology. Nat Neurosci 16:848-850

14. Wang Y, Cella M, Mallinson K, Ulrich JD, Young KL, Robinette ML, Gilfillan S, Krishnan GM, Sudhakar S, Zinselmeyer BH, Holtzman DM, Cirrito JR, Colonna M (2015) TREM2 lipid sensing sustains the microglial response in an Alzheimer's disease model. Cell 160:1061-1071

15. Griciuc A, Serrano-Pozo A, Parrado AR, Lesinski AN, Asselin CN, Mullin K, Hooli B, Choi SH, Hyman BT, Tanzi RE (2013) Alzheimer's disease risk gene CD33 inhibits microglial uptake of amyloid beta. Neuron 78:631-643

16. Christie RH, Freeman M, Hyman BT (1996) Expression of the macrophage scavenger receptor, a multifunctional lipoprotein receptor, in microglia associated with senile plaques in Alzheimer's disease. Am J Pathol 148:399-403

17. Wilkinson K, El Khoury J (2012) Microglial scavenger receptors and their roles in the pathogenesis of Alzheimer's disease. Int J Alzheimers Dis 2012:489456

18. El Khoury J, Hickman SE, Thomas CA, Cao L, Silverstein SC, Loike JD (1996) Scavenger receptor-mediated adhesion of microglia to beta-amyloid fibrils. Nature 382:716-719

19. Paresce DM, Ghosh RN, Maxfield FR (1996) Microglial cells internalize aggregates of the Alzheimer's disease amyloid betaprotein via a scavenger receptor. Neuron 17:553-565

20. Chung H, Brazil MI, Irizarry MC, Hyman BT, Maxfield FR (2001) Uptake of fibrillar beta-amyloid by microglia isolated from MSR-A (type I and type II) knockout mice. Neuroreport 12:1151-1154

21. Frenkel D, Wilkinson K, Zhao L, Hickman SE, Means TK, Puckett L, Farfara D, Kingery ND, Weiner HL, El Khoury J (2013) Scaral deficiency impairs clearance of soluble amyloid-beta by mononuclear phagocytes and accelerates Alzheimer's-like disease progression. Nat Commun 4:2030

22. Sandoval K, Umbaugh D, House A, Crider A, Witt K (2019) Somatostatin Receptor Subtype-4 Regulates mRNA Expression of Amyloid-Beta Degrading Enzymes and Microglia Mediators of Phagocytosis in Brains of 3xTg-AD Mice. Neurochem Res 44: 2670-2680

23. Suzuki H, Kurihara Y, Takeya M, Kamada N, Kataoka M, Jishage K, Ueda O, Sakaguchi H, Higashi T, Suzuki T, Takashima Y, Kawabe Y, Cynshi O, Wada Y, Honda M, Kurihara H, Aburatani H, Doi T, Matsumoto A, Azuma S, Noda T, Toyoda Y, Itakura H, Yazaki Y, Horiuchi S, Takahashi K, Kruijt JK, van Berkel TJC, Steinbrecher UP, Ishibashi S, Maeda N, Gordon S, Kodama T (1997) A role for macrophage scavenger receptors in atherosclerosis and susceptibility to infection. Nature 386:292-296

24. Zhu C, Schwarz P, Abakumova I, Aguzzi A (2015) Unaltered Prion Pathogenesis in a Mouse Model of High-Fat Diet-Induced Insulin Resistance. PLoS One 10:e0144983

25. Frontzek K, Pfammatter M, Sorce S, Senatore A, Schwarz P, Moos R, Frauenknecht K, Hornemann S, Aguzzi A (2016) Neurotoxic Antibodies against the Prion Protein Do Not Trigger Prion Replication. PLoS One 11:e0163601

26. Bell MD, Lopez-Gonzalez R, Lawson L, Hughes D, Fraser I, Gordon S, Perry VH (1994) Upregulation of the macrophage scavenger receptor in response to different forms of injury in the CNS. J Neurocytol 23:605-613

27. Grewal RP, Yoshida T, Finch CE, Morgan TE (1997) Scavenger receptor mRNAs in rat brain microglia are induced by kainic acid lesioning and by cytokines. Neuroreport 8:1077-1081

28. Honda M, Akiyama H, Yamada Y, Kondo H, Kawabe Y, Takeya M, Takahashi K, Suzuki H, Doi T, Sakamoto A, Ookawara S, Mato M, Gough PJ, Greaves DR, Gordon S, Kodama T, Matsushita M (1998) Immunohistochemical evidence for a macrophage scavenger receptor in Mato cells and reactive microglia of ischemia and Alzheimer's disease. Biochem Biophys Res Commun 245:734 740 
29. Bornemann KD, Wiederhold KH, Pauli C, Ermini F, Stalder M, Schnell L, Sommer B, Jucker M, Staufenbiel M (2001) Abetainduced inflammatory processes in microglia cells of APP23 transgenic mice. Am J Pathol 158:63-73

30. Sorce S, Nuvolone M, Russo G, Chincisan A, Heinzer D, Avar M, Pfammatter M, Schwarz P, Delic M, Muller M et al (2020) Genome-wide transcriptomics identifies an early preclinical signature of prion infection. PLoS Pathog 16:e1008653

31. Scheckel C, Imeri M, Schwarz P, Aguzzi A (2020) Ribosomal profiling during prion disease uncovers progressive translational derangement in glia but not in neurons. Elife 9:e62911

32. Bueler H, Raeber A, Sailer A, Fischer M, Aguzzi A, Weissmann C (1994) High prion and PrPSc levels but delayed onset of disease in scrapie-inoculated mice heterozygous for a disrupted PrP gene. Mol Med 1:19-30

33. Fischer M, Rulicke T, Raeber A, Sailer A, Moser M, Oesch B, Brandner S, Aguzzi A, Weissmann C (1996) Prion protein (PrP) with amino-proximal deletions restoring susceptibility of $\operatorname{PrP}$ knockout mice to scrapie. EMBO J 15:1255-1264

34. Peiser L, Mukhopadhyay S, Gordon S (2002) Scavenger receptors in innate immunity. Curr Opin Immunol 14:123-128

35. Areschoug T, Gordon S (2009) Scavenger receptors: role in innate immunity and microbial pathogenesis. Cell Microbiol 11:11601169

36. Canton J, Neculai D, Grinstein S (2013) Scavenger receptors in homeostasis and immunity. Nat Rev Immunol 13:621-634

37. Aguzzi A, Barres BA, Bennett ML (2013) Microglia: scapegoat, saboteur, or something else? Science 339:156-161

38. Baker M, Mackenzie IR, Pickering-Brown SM, Gass J, Rademakers R, Lindholm C, Snowden J, Adamson J, Sadovnick AD, Rollinson S, Cannon A, Dwosh E, Neary D, Melquist S, Richardson A, Dickson D, Berger Z, Eriksen J, Robinson T, Zehr C, Dickey CA, Crook R, McGowan E, Mann D, Boeve B, Feldman $\mathrm{H}$, Hutton M (2006) Mutations in progranulin cause tau-negative frontotemporal dementia linked to chromosome 17. Nature 442: 916-919

39. Cruts M, Gijselinck I, van der Zee J, Engelborghs S, Wils H, Pirici D, Rademakers R, Vandenberghe R, Dermaut B, Martin JJ, van Duijn C, Peeters K, Sciot R, Santens P, de Pooter T, Mattheijssens M, van den Broeck M, Cuijt I, Vennekens K', de Deyn PP, Kumar-Singh S, van Broeckhoven C (2006) Null mutations in progranulin cause ubiquitin-positive frontotemporal dementia linked to chromosome 17q21. Nature 442:920-924

40. Hollingworth P, Harold D, Sims R, Gerrish A, Lambert JC, Carrasquillo MM, Abraham R, Hamshere ML, Pahwa JS, Moskvina V et al (2011) Common variants at ABCA7, MS4A6A/MS4A4E, EPHA1, CD33 and CD2AP are associated with Alzheimer's disease. Nat Genet 43:429-435

41. Naj AC, Jun G, Beecham GW, Wang LS, Vardarajan BN, Buros J, Gallins PJ, Buxbaum JD, Jarvik GP, Crane PK, Larson EB, Bird TD, Boeve BF, Graff-Radford NR, de Jager PL, Evans D, Schneider JA, Carrasquillo MM, Ertekin-Taner N, Younkin SG, Cruchaga C, Kauwe JSK, Nowotny P, Kramer P, Hardy J, Huentelman MJ, Myers AJ, Barmada MM, Demirci FY, Baldwin CT, Green RC, Rogaeva E, George-Hyslop PS, Arnold SE, Barber R, Beach T, Bigio EH, Bowen JD, Boxer A, Burke JR, Cairns NJ, Carlson CS, Carney RM, Carroll SL, Chui HC, Clark DG, Corneveaux J, Cotman CW, Cummings JL, DeCarli C, DeKosky ST, Diaz-Arrastia R, Dick M, Dickson DW, Ellis WG, Faber KM, Fallon KB, Farlow MR, Ferris S, Frosch MP, Galasko DR, Ganguli M, Gearing M, Geschwind DH, Ghetti B, Gilbert JR, Gilman S,
Giordani B, Glass JD, Growdon JH, Hamilton RL, Harrell LE, Head E, Honig LS, Hulette CM, Hyman BT, Jicha GA, Jin LW, Johnson N, Karlawish J, Karydas A, Kaye JA, Kim R, Koo EH, Kowall NW, Lah JJ, Levey AI, Lieberman AP, Lopez OL, Mack WJ, Marson DC, Martiniuk F, Mash DC, Masliah E, McCormick WC, McCurry SM, McDavid AN, McKee AC, Mesulam M, Miller BL, Miller CA, Miller JW, Parisi JE, Perl DP, Peskind E, Petersen RC, Poon WW, Quinn JF, Rajbhandary RA, Raskind M, Reisberg B, Ringman JM, Roberson ED, Rosenberg RN, Sano M, Schneider LS, Seeley W, Shelanski ML, Slifer MA, Smith CD, Sonnen JA, Spina S, Stern RA, Tanzi RE, Trojanowski JQ, Troncoso JC, van Deerlin VM, Vinters HV, Vonsattel JP, Weintraub S, WelshBohmer KA, Williamson J, Woltjer RL, Cantwell LB, Dombroski BA, Beekly D, Lunetta KL, Martin ER, Kamboh MI, Saykin AJ, Reiman EM, Bennett DA, Morris JC, Montine TJ, Goate AM, Blacker D, Tsuang DW, Hakonarson H, Kukull WA, Foroud TM, Haines JL, Mayeux R, Pericak-Vance MA, Farrer LA, Schellenberg GD (2011) Common variants at MS4A4/MS4A6E, CD2AP, CD33 and EPHA1 are associated with late-onset Alzheimer's disease. Nat Genet 43:436-441

42. Sierksma A, Lu A, Mancuso R, Fattorelli N, Thrupp N, Salta E, Zoco J, Blum D, Buee L, De Strooper B et al (2020) Novel Alzheimer risk genes determine the microglia response to amyloid-beta but not to TAU pathology. EMBO Mol Med 12: e10606

43. Bartels T, De Schepper S, Hong S (2020) Microglia modulate neurodegeneration in Alzheimer's and Parkinson's diseases. Science 370:66-69

44. Paolicelli RC, Bolasco G, Pagani F, Maggi L, Scianni M, Panzanelli P, Giustetto M, Ferreira TA, Guiducci E, Dumas L, Ragozzino D, Gross CT (2011) Synaptic pruning by microglia is necessary for normal brain development. Science 333:1456-1458

45. Parkhurst CN, Yang G, Ninan I, Savas JN, Yates JR 3rd, Lafaille JJ, Hempstead BL, Littman DR, Gan WB (2013) Microglia promote learning-dependent synapse formation through brain-derived neurotrophic factor. Cell 155:1596-1609

46. Nimmerjahn A, Kirchhoff F, Helmchen F (2005) Resting microglial cells are highly dynamic surveillants of brain parenchyma in vivo. Science 308:1314-1318

47. Davalos D, Grutzendler J, Yang G, Kim JV, Zuo Y, Jung S, Littman DR, Dustin ML, Gan WB (2005) ATP mediates rapid microglial response to local brain injury in vivo. Nat Neurosci 8: $752-758$

48. Husemann J, Loike JD, Anankov R, Febbraio M, Silverstein SC (2002) Scavenger receptors in neurobiology and neuropathology: their role on microglia and other cells of the nervous system. Glia 40:195-205

49. Cheng C, Hu Z, Cao L, Peng C, He Y (2019) The scavenger receptor SCARA1 (CD204) recognizes dead cells through spectrin. J Biol Chem 294:18881-18897

50. Hickman SE, Allison EK, El Khoury J (2008) Microglial dysfunction and defective beta-amyloid clearance pathways in aging Alzheimer's disease mice. J Neurosci 28:8354-8360

51. von Bernhardi R, Cornejo F, Parada GE, Eugenin J (2015) Role of TGFbeta signaling in the pathogenesis of Alzheimer's disease. Front Cell Neurosci 9:426

Publisher's note Springer Nature remains neutral with regard to jurisdictional claims in published maps and institutional affiliations. 